\title{
Judicialization of coagulation factors in severe hemophilia: compliance with the care protocol and associated factors Judicialization and severe hemophilia
}

\author{
Beatriz Mac Dowell Soares ${ }^{1 *}$ (D), Luiz Alberto Simeoni ${ }^{1}$, \\ Karlo Jozefo Quadros de Almeida² (1), Jaqueline Lima de Souza ${ }^{3}$ (D),

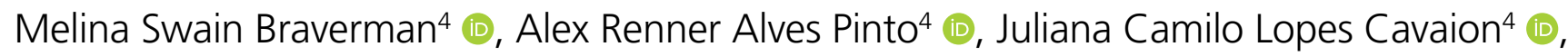 \\ Lucas Barbosa Bezerra ${ }^{3}$ (1), Ana Maria Costa ${ }^{5}$ (D), Fábio Ferreira Amorim ${ }^{5}$
}

\section{SUMMARY}

OBJECTIVE: This study aimed to analyze the compliance with the assistance protocol and factors associated with the judicialization of coagulation factors in severe hemophilia patients.

METHODS: A retrospective, cross-sectional study was conducted from June 2015 to May 2016 in adults with severe hemophilia in the Federal District, Brazil using data from their medical records and the Hemovida Web Coagulopathies System.

RESULTS: One-hundred and three patients from Federal District, the capital of Brazil, were included in the study. The mean age of the

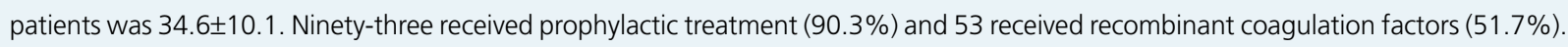
Judicialization occurred in 21 cases (20.4\%), 13 of whom disagreed with the assistance protocol (12.6\%). In the univariate analysis, an association was observed between reduced judicialization and treatment (4.8 vs. $47.6 \% ; \mathrm{p}<0.001)$ in the hemophilia treatment center and an increase that was associated with use of the recombinant coagulation factor in disagreement with the protocol (38.1 vs. $6.1 \%$; $\mathrm{p}<0.001$ ). In the multivariate analysis, the odds ratio for judicialization was 0.081 (95\% confidence interval [CI] 0.010-0.055) for treatment at the hemophilia treatment center and $5.067(95 \% \mathrm{Cl} 1.392-18.446)$ for the use of recombinant coagulation factor not in compliance with the protocol. More inhibitor development in judicialized patients ( 33.3 vs. $4.9 \%$; $p<0.001$ ) was found.

CONCLUSIONS: The effectiveness of judicialization should be questioned, especially regarding coagulation factor prescriptions that are not in compliance with the protocol. The expense resulting from judicialization has not shown any benefit, and an even greater development of inhibitors during treatment in judicialized patients was found.

KEYWORDS: Legislation, jurisprudence. Hemophilia A. Hemophilia B. Factor VIII. Factor IX. Pharmaceutical services. Health services. Health services accessibility.

\footnotetext{
`Universidade de Brasília, Programa de Pós-Graduação em Ciências da Saúde, Brasília (DF), Brazil. ${ }^{2}$ Hospital Regional da Asa Norte, Brasília (DF), Brazil.

${ }^{3}$ Escola Superior de Ciências da Saúde, Curso de Graduação Brasília em Medicina, Brasília (DF), Brazil.

${ }^{4}$ Fundação Hemocentro de Brasília, Escola Superior de Ciências da Saúde, Brasília (DF), Brazil.

${ }^{5}$ Escola Superior de Ciências da Saúde, Coordenação de Pós-Graduação e Extensão Saúde, Brasília (DF), Brazil.

*Corresponding author: biamacdowell@uol.com.br

Conflicts of interest: the authors declare that there are no conflicts of interest. Funding: none.

Received on August 18, 2020. Accepted on September 30, 2020.
} 


\section{INTRODUCTION}

Hemophilia is a rare, inherited disorder linked to the $\mathrm{X}$ chromosome characterized by the deficiency of coagulation factor VIII (hemophilia A) or IX (hemophilia B), which leads to bleeding. The treatment is the replacement of coagulation factors (plasma or recombinant) ${ }^{1,2}$, which aims to reduce bleeding and prevent sequelae and high mortality rates.

Brazil has the fourth largest population of hemophilia patients worldwide (12,432 people) according to the 2017 Annual Global Survey of the World Federation of Hemophilia, behind the United States, India, and China ${ }^{3}$. To guarantee treatment, the Brazilian Ministry of Health (MS) acquires and distributes coagulation factors free of charge to users of the Unified Health System (SUS) ${ }^{4}$, which has incorporated innovations during the last decade for the care of people with hemophilia. These innovations have been incorporated as the national registry of users with hereditary hemorrhagic disorders (Hemovida Web Coagulopathies System $)^{5}$ and include the implantation of primary prophylaxis with regular replacement of coagulation factors for patients below 36 months of age ${ }^{6}$ and secondary prophylaxis for older people and young children ${ }^{7}$. In 2013, in hemophilia A, recombinant FVIII was incorporated for patients under the age of 30 years $^{8}$.

In the Federal District (FD), prophylactic treatment for hemophilia was implemented in $2011^{9}$ and revised in 2012 to adapt to the MS guidelines ${ }^{10}$. From the disclosure of the protocol among the assisting professionals, an adjustment of the demand for the products was foreseen with reduction of the judicialization, given that the availability was compatible with the demand. However, a persistence of lawsuits has occurred ${ }^{11}$.

Legal actions related to the right to health, described now as the judicialization of health, have been increasing in Brazil. As an example, between 2016 and 2017, an increase of approximately $50 \%$ in these processes was found ${ }^{11,12}$. In the FD, a study showed that there was an increase in lawsuits over time related to the right to health care without further discussion of the economic aspects since when a claim is granted; the Executive Branch is forced to reduce investment in other health-related actions or policies. This privileges the individual at the expense of the collective, which is contrary to the principle of equity and isonomy leading to the detriment of efficiency itself ${ }^{1}$. Another study in the FD showed that all processes were individual and not collective actions ${ }^{13}$.

In this context, this study aimed to analyze compliance with the care protocol and factors associated with the judicialization of coagulation factors in patients with severe hemophilia.

\section{METHODS}

This study was conducted as a retrospective cross-sectional study from June 2015 to May 2016 based on data from patient medical records and the Hemovida Web Coagulopathies System of $\mathrm{MS}^{5}$, including patients with severe hemophilia, those who were aged 18 or above, and those who resided in FD or in the municipalities of RIDE-FD ( $\mathrm{n}=103)$. In addition, records of product dispensations were also consulted in the pharmacy of Fundação Hemocentro de Brasília (FHB).

Data, including age, weight, place of treatment (FHB or other), place of residence, type of treatment (demand or prophylaxis), access to treatment (judicial or not), dose by infusion, number of weekly doses, and type of coagulation factor prescribed (plasma or recombinant), tests for inhibitory antibodies, and serology for blood-borne infectious diseases (hepatitis viruses $B$ and $\mathrm{C}$ [HBV and $\mathrm{HCV}$, respectively], human immunodeficiency and human T-lymphotropic viruses [HIV and HTLV, respectively], and Chagas disease), were collected. Serological tests were performed using the chemiluminescence method (Abbott) in the FHB laboratory. Severe hemophilia was defined by the levels of clotting factors $<1 \%{ }^{3}$.

The normality of data distribution was assessed using the Kolmogorov-Smirnov test. Quantitative data were expressed as mean \pm standard deviation (SD) or median and the $25-75 \%$ interquartile range (IQ 25-75\%). Categorical variables were expressed as numbers and percentages (\%). When appropriate, the Student's $t$-test or Mann-Whitney $U$ test was used to compare quantitative variables. For categorical variables, contingency tables and Pearson's chi-square $\left(\chi^{2}\right)$ or Fisher's exact test were used as appropriate. To assess independent factors associated with judicialization, noncollinear variables with a $\mathrm{p}<0.20$ in the univariate analysis were assessed by binary logistic regression analysis using the stepwise method. Data were analyzed by using the IBM Statistical Package for the Social Sciences (SPSS) software program, version 20.0 for Mac (SPSS, Chicago, Illinois, USA). Statistical significance level was defined as two-tailed $\mathrm{p}<0.05$.

The study was approved by the Research Ethics Committee of the Health Sciences Teaching and Research Foundation (FEPECS), Brasília, Distrito Federal, Brazil.

\section{RESULTS}

The mean age of the included patients ( $n=103)$ was $34.2 \pm 10.1$ years. Approximately $70.9 \%$ were residents of the FD and $38.8 \%$ underwent treatment at the referral care unit, the FHB. Ninety-three patients received prophylactic treatment $(90.3 \%)$ and 53 patients (51.7\%) received recombinant factors. In 13 cases, use was at odds with the protocol (12.6\%). Judicialization occurred in 21 cases $(20.4 \%)$. The median consumption of clotting factors per kg was 37.0 IU of FVIII (IQ 25-75\%: 31.0-41.0) and 40.0 IU of FIX (IQ 25-75\%: 35.5-54.0) as shown in Table 1. 
Table 2 presents the univariate and multivariate analyses of the factors associated with judicialization. In the univariate analysis, a significant association was observed between reduced judicialization and treatment in the reference care unit $(\mathrm{p}<0.001)$. On the contrary, using recombinant FVIII in disagreement with the protocol was associated with greater judicialization $(\mathrm{p}<0.001)$. No significant differences were found in relation to other variables. In the multivariate analysis, a significant association was maintained between increased judicialization and the use of recombinant FVIII in disagreement with the protocol $(\mathrm{p}=0.014)$ and a reduction associated with treatment in the reference care unit $(\mathrm{p}=0.018)$. The odds

Table 1. Baseline data of adult patients with severe hemophilia $(n=103)$.

\begin{tabular}{|c|c|}
\hline Age, years, mean (SD) & $34.2(10.1)$ \\
\hline Hemophilia A, n (\%) & $79(76.7)$ \\
\hline Judicial treatment, n (\%) & $21(20.4)$ \\
\hline Residence in the Federal District, n (\%) & $73(70.9)$ \\
\hline Use of the reference care unit for treatment, $\mathrm{n}(\%)$ & $40(38.8)$ \\
\hline Presence of inhibitor, $\mathrm{n}(\%)$ & $11(10.7)$ \\
\hline Prophylactic treatment, n (\%) & $93(90.3)$ \\
\hline Use of recombinant coagulation factor, n (\%) & $53(51.5)$ \\
\hline Use of recombinant coagulation factor in disagreement with protocol, $\mathrm{n}(\%)$ & $13(12.6)$ \\
\hline \multicolumn{2}{|l|}{ Coagulation factor VIII } \\
\hline Infusion IU in patients with hemophilia A, median (IQ 25-75\%)\# & $3.000(2.500-3.000)$ \\
\hline Infusion IU and weight in patients with hemophilia A, IU/kg, median (IQ 25-75\%)\# & $37.0(31.0-41.0)$ \\
\hline Doses per week in patients with hemophilia A, median (IQ 25-75\%)\# & $4.0(3.0-4.0)$ \\
\hline IU dispensed per month in patients with hemophilia A, median (IQ 25-75\%)\# & $48.000(30.000-60.000)$ \\
\hline \multicolumn{2}{|l|}{ Coagulation factor IX } \\
\hline Infusion IU in patients with hemophilia B, median (IQ 25-75\%)* & $3.000(3.000-3.500)$ \\
\hline IU by infusion and weight in patients with hemophilia B, IU/kg, median (IQ 25-75\%)* & $40.0(35.5-54.0)$ \\
\hline Doses per week in patients with hemophilia B, median (IQ 25-75\%)* & $3.0(2.0-3.0)$ \\
\hline IU dispensed per month in patients with hemophilia B, median (IQ 25-75\%)* & $35.500(16.875-46.000)$ \\
\hline
\end{tabular}

IU: international units of coagulation factor; SD: standard deviation; IQ 25-75\%: interquartile range 25-75\%; \#79 patients with hemophilia A; *24 patients with hemophilia B.

Table 2. Univariate and multivariate analyses of factors associated with judicialization in adult patients with severe hemophilia ( $n=103)$.

\begin{tabular}{l|c|c|c|c} 
& $\begin{array}{c}\text { Judicialized } \\
(\mathrm{n}=21)\end{array}$ & $\begin{array}{c}\text { Not judicialized } \\
(\mathrm{n}=82)\end{array}$ & $\begin{array}{c}\text { Univariate } \\
\text { analysis: } \mathrm{p} \text {-value }\end{array}$ & $\begin{array}{c}\text { Multivariate } \\
\text { analysis: } \mathrm{p} \text {-value }\end{array}$ \\
\hline Age, years, mean (SD) & $34.2(9.1)$ & $34.2(10.4)$ & 0.991 & - \\
\hline Hemophilia A, $\mathrm{n}(\%)$ & $5(23.8)$ & $19(23.2)$ & 0.951 & 0.018 \\
\hline $\begin{array}{l}\text { Use of the reference care unit for } \\
\text { treatment, } \mathrm{n}(\%)\end{array}$ & $1(4.8)$ & $39(47.6)$ & $<0.001$ & - \\
\hline Residence in the Federal District, $\mathrm{n}(\%)$ & $15(71.4)$ & $58(70.7)$ & 0.950 & - \\
\hline Prophylactic treatment, $\mathrm{n}(\%)$ & $19(90.5)$ & $74(90.2)$ & 0.974 & 0.014 \\
\hline $\begin{array}{l}\text { Use of recombinant factor in } \\
\text { disagreement with protocol, } \mathrm{n}(\%)\end{array}$ & $8(38.1)$ & $5(6.1)$ & $<0.001$ & - \\
\hline
\end{tabular}

SD: standard deviation; 95\% Cl: 95\% confidence interval. 
ratio for judicialization was 0.081 ( $95 \%$ confidence interval [CI] 0.010-0.055) for treatment in the reference care unit and 5.067 (95\%CI 1.392-18.446) for recombinant FVIII not in accordance with the protocol.

Table 3 compares the results of serologies for bloodborne diseases and antibodies that inhibit coagulation factors during treatment between judicial and non-judicial patients. Patients receiving judicial treatment had a higher incidence of antibodies that inhibited coagulation factors (33.3 vs. $4.9 \%$, $p<0.001)$. Regarding serology, no significant differences were observed between groups.

\section{DISCUSSION}

Judicialization of coagulation factors has become a persistent phenomenon even after the adoption of the care protocol in the FD. This phenomenon is associated with the use of recombinant factors in disagreement with the protocol, which becomes, in particular, a problem for managers because it is a product with high costs. Treatment at the referral care unit was associated with reduced judicialization, which shows the importance of monitoring at a trained center to deal with care for people with hemophilia ${ }^{14}$. More inhibitory antibodies in judicialized patients were found with no significant difference in relation to serologies for infectious diseases, and it can be inferred that judicialization did not benefit this set of patients with respect to any of these aspects. As already observed in a previous study, a higher consumption of coagulation factors in the FD when compared with other Brazilian states was demonstrated ${ }^{12}$.

SUS is a universal health system that requires strategies for guaranteeing equity and quality. From this perspective, clinical treatment protocols aim to promote safety, efficacy, and cost-effectiveness in treatment ${ }^{15}$. In healthcare for patients with hemophilia, these requirements are important, and monitoring of pharmacological treatment, bleeding, and development of inhibitors is relevant ${ }^{2,16}$. Most of the studied patients used prophylaxis as they were young, productive people who would benefit from this monitoring in the perspective of longevity with quality of life. In relation to hemophilia A, in 2013, the Ministry of Health started to make recombinant FVIII available to patients at ages $<30$ in order to guarantee treatment as blood products are dependent on blood donors and more vulnerable to fluctuations in availability ${ }^{8}$. The disadvantage of recombinant FVIII is the cost, which was 2.6-3.2 times higher than that of plasma during the research period ${ }^{17}$.

Approximately half of the patients used recombinant factors, and a quarter of them had prescriptions in disagreement with the protocol, which was associated with the increased judicialization. It is noteworthy that the judicial demand was granted even with a prescription different from the protocol, thus demonstrating the need for mechanisms for consultation between the judiciary and SUS managers. Furthermore, as the coagulation factors have been supplied to the FD by the Ministry of Health in quantities greater than other units of the federation, there is no justification for this judicialization ${ }^{18}$.

Hemophilia is a rare disease with complex treatment. Healthcare professionals must have knowledge and experience to deal with its peculiarities. Studies point out the importance of reference centers in which several services are offered with a multidisciplinary team. In addition to health-related aspects, the establishment of referral centers can reduce costs and improve the long-term results. Greater judicialization by unaccompanied users in the reference center indicates to managers the

Table 3. Inhibitors of coagulation factors and serologies for blood-borne infectious diseases among judicial and non-judicial patients in adult patients with severe hemophilia $(n=103)$.

\begin{tabular}{l|c|c|c} 
& $\begin{array}{c}\text { Judicialized } \\
(\mathrm{n}=21)\end{array}$ & $\begin{array}{c}\text { Not judicialized } \\
(\mathrm{n}=82)\end{array}$ & p-value \\
\hline Coagulation factor inhibitor, $\mathrm{n}(\%)$ & $7(33.3)$ & $4(4.9)$ & $<0.001$ \\
\hline Anti-HCV positive, $\mathrm{n}(\%)$ & $12(57.2)$ & $44(53.7)$ & 0.775 \\
\hline Anti-HIV positive, $\mathrm{n}(\%)^{*}$ & $2(9.5)$ & $3(3.7)$ & 0.271 \\
\hline Anti-HTLV 1/2 positive, $\mathrm{n}(\%)$ & $0(0.0)$ & $2(2.4)$ & 0.470 \\
\hline Anti-HBc positive, $\mathrm{n}(\%)$ & $3(14.3)$ & $19(23.2)$ & 0.375 \\
\hline HBsAg positive, $\mathrm{n}(\%)$ & $0(0.0)$ & $1(1.2)$ & 0.611 \\
\hline Anti-HBc e HBsAg positive, $\mathrm{n}(\%)$ & $0(0.0)$ & $1(1.2)$ & 0.611 \\
\hline Serology for positive Chagas disease, $\mathrm{n}(\%)$ & $0(0.0)$ & $4(4.9)$ & 0.302 \\
\hline
\end{tabular}

HCV: hepatitis C vírus; HIV: human immunodeficiency vírus; HTLV 1/2: human T-cell lymphotropic viruses 1 and 2; HBc: hepatitis B virus core antigen; HBsAg: hepatitis B virus surface antigen; *One patient did not undergo HIV serological tests. 
need to reinforce the dissemination of this service for other health services ${ }^{19-22}$.

It is worth noting that no evidence of greater safety for recombinant factors in relation to plasma can be found ${ }^{23,24}$. In the present study, a greater development of inhibitors in judicialized patients with no difference in serology for bloodborne diseases was observed. These findings show the safety of blood-derived factors in relation to the transmission of infectious diseases after the introduction of donor serological screening and methods of viral elimination and inactivation in the products derivate of blood ${ }^{4,22,25}$.

Limitations existed in our study. Since hemophilia is a rare disease, it is difficult to conduct a study with larger populations. Furthermore, as this was a retrospective study, it was not possible to obtain other variables, such as quality of life, as no record of this parameter and other parameters exists in the medical record.

\section{CONCLUSIONS}

The effectiveness of judicialization should be questioned, especially regarding the use of recombinant factors that are not in accordance with the assistance protocol. The expense resulting from judicialization has shown no benefit even with greater development of antibodies that inhibit coagulation factors in judicialized patients; this expense represents an unnecessary cost that could be applied to other needs of patients with hemophilia in addition to other health conditions. It is imperative to establish a relationship with organized civil society, district, and federal bodies, including the judiciary, in the search for a trusting relationship, in defense of the SUS, and for the quality and safety of patient healthcare.

\section{AUTHORS" CONTRIBUTIONS}

BMDS: Conceptualization, Data Curation, Formal Analysis, Writing - Original Draft, Writing - Review \& Editing. KJQA: Conceptualization, Resources, Writing - Review \& Editing. AMC: Conceptualization, Data Curation, Writing Review \& Editing. FFA: Conceptualization, Formal Analysis, Writing - Original Draft, Writing - Review \& Editing. MSB: Data Curation, Resources, Writing - Review \& Editing. ARAP: Data Curation, Resources, Writing - Review \& Editing. JCLC: Data Curation, Resources, Writing - Review \& Editing. LAS: Formal Analysis, Resources, Writing - Original Draft, Writing - Review \& Editing. JLS: Data Curation, Resources, Writing - Review \& Editing. LBB: Data Curation, Resources, Writing - Review \& Editing.

\section{REFERENCES}

1. Jardim LL, van der Bom JG, Caram-Deelder C, Gouw SC, Leal Cherchiglia M, Meireles Rezende S. Mortality of patients with haemophilia in Brazil: First report. Haemophilia. 2019;25(3): e146-52. https://doi.org/10.1111/hae.13730

2. Srivastava A, Brewer AK, Mauser-Bunschoten EP, Key NS, Kitchen S, Llinas A, et al. Guidelines for the management of hemophilia. Haemophilia. 2013;19(1): e1-47. https://doi. org/10.1111/j.1365-2516.2012.02909.x

3. World Federation of Haemophilia (WFH). Annual Global Survey 2017. Montreal: World Federation of Haemophilia; 2017. [cited on Set. 10, 2020]. Available from: https://www1.wfh. org/publication/files/pdf-1690.pdf

4. BRASIL. Ministério da Saúde. Perfil das coagulopatias hereditárias no Brasil: 2009-2010. Brasília: Ministério da Saúde; 2012.

5. Barca DAAV, Rezende SM, Simões BJ, Pinheiro KN, Daisson T, Sternick G, et al. Hemovida web coagulopatias: um relato do seu processo de desenvolvimento e implantação. Cad Saude Colet [Internet]; 2010 [cited on Sept. 10, 2020];18(3):434-5. Available from: https://pesquisa.bvsalud.org/portal/resource/ pt/lil-593741

6. BRASIL. Ministério da Saúde. Relatório de gestão 2011 [da] coordenação geral de sangue e hemoderivados. Brasília: Ministério da Saúde; 2012.
7. BRASIL. Ministério da Saúde. Relatório de gestão 2012 [da] Coordenação Geral de Sangue e Hemoderivados. Brasília: Ministério da Saúde; 2013.

8. BRASIL. Ministério da Saúde. Relatório de gestão 2013 [da] Coordenação-Geral de Sangue Hemoderivados. Brasília: Ministério da Saúde; 2015.

9. Distrito Federal. Secretaria de Estado de Saúde. Portaria SES-DF $n^{\circ} 113$, de 7 de julho de 2011. Aprova os Protocolos Clínicos e de Dispensação de Medicamentos elaborados pelas áreas técnicas da SES-DF e aprovados pela CPPAS. Diário Oficial do Distrito Federal; 2011.

10. Distrito Federal. Secretaria de Estado de Saúde. Portaria $\mathrm{n}^{\circ}$ 121, de 4 de julho de 2012. Aprova os Protocolos Clínicos e de Dispensação de Medicamentos elaborados pelas áreas técnicas de SES-DF e aprovados pela CPPAS. Diário Oficial do Distrito Federal; 2012.

11. Paixão ALS. Reflexões sobre a judicialização do direito à saúde e suas implicações no SUS. Cienc Saude Coletiva. 2019:24(6):216772. https://doi.org/10.1590/1413-81232018246.08212019

12. Silva EM, Almeida KC, Pessoa CGSC. Análise do gasto com judicialização de medicamentos no Distrito Federal, Brasil. Cad. Ibero Am. Direito Sanit. 2017;6(1):112-26. https://doi org/10.17566/ciads.v6i1.358 
13. Cardoso CS. Análise das demandas judiciais de medicamentos: Uma abordagem da realidade atual do Distrito Federal. Cad. Ibero Am. Direito Sanit. 2017;6(1):228-46. https://doi. org/10.17566/ciads.v6i1.369

14. Pai M, Key NS, Skinner M, Curtis R, Feinstein M, Kessler C, et al. NHF-McMaster Guideline on Care Models for Haemophilia Management. Haemophilia. 2016;22(Suppl 3):6-16. https:// doi.org/10.1111/hae. 13008

15. BRASIL. Lei $n^{\circ} 12.401$, de 28 de abril de 2011. Altera a Lei $n^{\circ} 8.080$, de 19 de setembro de 1990, para dispor sobre a assistência terapêutica e a incorporação de tecnologia em saúde no âmbito do Sistema Único de Saúde-SUS. Diário Oficial da União; 2011.

16. Canadian Hemophilia Society. Treatment of hemophilia. Montreal: Canadian Hemophilia Society; 2018. [cited on Set. 10, 2020]. Available from: https://www.hemophilia.ca/ treatment-of-hemophilia/

17. BRASIL. Ministério da Saúde. Acesso à Informação, consulta: Aquisição de medicamentos pró-coagulantes entre os anos 2009-2015. Brasília: Ministério da Saúde; 2020. [cited on Set. 10, 2020]. Available from: http://www.consultaesic.cgu. gov.br/busca/dados/Lists/Pedido/ltem/displayifs.aspx?List=0c839f31\%2D47d7\%2D4485\%2Dab65\%2Dab0cee9cf8fe\&l$D=493604 \& W e b=88 c c 5 f 44 \% 2 D 8 c f e \% 2 D 4964 \% 2 D 8 f f 4 \%-$ 2D376b5ebb3bef

18. BRASIL. Ministério da Saúde. Perfil das coagulopatias hereditárias no Brasil: 2016. Brasília: Ministério da Saúde; 2016.
19. Dalton DR. Hemophilia in the managed care setting. Am J Manag Care. 2015;21(6 Suppl):S123-30. PMID: 26168207

20. Ferreira AA, Leite IC, Bustamante-Teixeira MT, Guerra MR. Hemophilia A in Brazil - epidemiology and treatment developments. J Blood Med. 2014;5:175-84. https://doi.org/10.2147/JBM.S68234

21. Mazepa MA, Monahan PE, Baker JR, Riske BK, Soucie JM; US Hemophilia Treatment Center Network. Men with severe hemophilia in the United States: birth cohort analysis of a large national database. Blood. 2016;127(24):3073-81. https://doi. org/10.1182/blood-2015-10-675140

22. Schramm W, Gringeri A, Ljung R, Berger K, Crispin A, Bullinger $\mathrm{M}$, et al. Haemophilia care in Europe: the ESCHQoL study. Haemophilia. 2012;18(5):729-37. https://doi.org/10.1111/ j.1365-2516.2012.02847.x

23. Astermark J, Altisent C, Batorova A, Diniz MJ, Gringeri A, Holme PA, et al. Non-genetic risk factors and the development of inhibitors in haemophilia: a comprehensive review and consensus report. Haemophilia. 2010;16(5):747-66. https:// doi.org/10.1111/j.1365-2516.2010.02231.x

24. Plug I, Van Der Bom JG, Peters M, Mauser-Bunschoten EP, De Goede-Bolder A, Heijnen L, et al. Mortality and causes of death in patients with hemophilia, 1992-2001: a prospective cohort study. J Thromb Haemost. 2006;4(3):510-6. https:// doi.org/10.1111/j.1538-7836.2006.01808.x

25. Ruiz-Sáez A. Comprehensive Care in Hemophilia. Hematology. 2012;17(Suppl 1):S141-3. https://doi.org/10.1179/102453 312X13336169156492 